\title{
Paola Solombrino, The in house providing as a self-organization model for the public administration (Zamówienia in-house jako element modelu samoorganizacji administracji publicznej), "The Juridical Current" („Le Courant Juridique") vol. 79, December 2019, s. 74-90
}

Działania podmiotów publicznych w sferze gospodarczej, w tym przejawiające się w nabywaniu towarów lub usług, stanowią istotny element procesu integracji europejskiej. Jak wskazuje Paola Solobrino, ze względu na doniosłą rolę oddziaływania podmiotów publicznych na kształtowanie unijnej gospodarki sposób nabywania towarów lub usług każdorazowo musi pozostawać w zgodności z Traktatem o funkcjonowaniu Unii Europejskiej (TFUE), który z jednej strony kładzie nacisk na kwestie rynkowe, a $z$ drugiej na prawa państw członkowskich do samoorganizowania administracji publicznej. Z powyższym korespondują regulacje zamówieniowe, które ograniczająco wpływają na swobodę podmiotów publicznych w nabywaniu dostaw, usług lub robót budowlanych. Niemniej jednak, zdaniem autorki, nie uchylają one prawa podmiotów publicznych do wyboru pomiędzy eksternalizacją a internalizacją realizacji zadań publicznych, a także nie ustanawiają paradygmatu zamówień publicznych.

W unijnym prawie zamówień publicznych dopuszczalność stosowania zamówień in-house (art. 12 dyrektywy 2014/24/UE) stanowi wyraz próby pogodzenia otwartości na konkurencję oraz prawa państw członkowskich do samoorganizowania administracji publicznej. Powyższe autorka zestawia z regulacjami prawa włoskiego oraz orzecznictwem włoskich sądów, które zamówienia in-house postrzegają jako wyjątek od realizacji zadań publicznych poprzez eksternalizację ich wykonania. Przyjęta przez ustawodawcę oraz judykaturę optyka ma bezpośrednie przełożenie na praktykę realizacji zadań publicznych, wobec istnienia we Włoszech wielu spółek publicznych, w tym spółek komunalnych, powołanych do realizacji zadań publicznych, np. w sektorze odpadów komunalnych, transportu, usług cmentarnych czy utrzymania dróg. Autorka szczegółowo odnosi kwestię zamówień wewnętrznych do branży IT, która zyskuje na coraz większym znaczeniu w dobie informatyzacji administracji publicznej. Jej rozwój, w połączeniu z konieczno- 
ścią dbałości o przestrzeganie m.in. regulacji dotyczących ochrony danych osobowych, otwiera nową przestrzeń dla rozważań dotyczących zamówień wewnętrznych.

Regulacje art. 12 dyrektywy 2014/24/UE zostały przeniesione do art. 5 włoskiej ustawy o zamówieniach publicznych (Code of public contracts). W swojej konstrukcji nie odbiegają one od unijnego pierwowzoru, tj. wyrażają wyłączenie stosowania przepisów dotyczących zamówień publicznych. Zostały one uzupełnione regulacjami swoistymi dla prawa włoskiego (specjalnym reżimem dla udzielania zamówień wewnętrznych). Przepis art. 192 ust. 1 włoskiej ustawy o zamówieniach publicznych ustanawia obowiązek zgłoszenia udzielania zamówienia in-house włoskiemu urzędowi antykorupcyjnemu (The Italian Anticorruption Authority). Obowiązek ten ma charakter informacyjny, a dokonywany na jego podstawie wpis do rejestru instytucji zamawiających i podmiotów zamawiających działających w formule in-house ma charakter deklaratoryjny. Nie warunkuje on dopuszczalności udzielenia zamówienia in-house w sposób, w jaki czynią to przesłanki wyrażone w art. 5 włoskiej ustawy o zamówieniach publicznych. Realizacja obowiązku rejestracyjnego nie rodzi domniemania zgodności udzielenia zamówienia wewnętrznego z przepisami włoskiej ustawy o zamówieniach publicznych. Spełnienie obowiązku ma służyć zwiększeniu transparentności współpracy bezpośredniej pomiędzy członkami struktury administracji publicznej. Podobne znaczenie ma obowiązkowe ujawnienie poprzez opublikowanie w ogólnodostępnym formacie danych oraz w sposób transparentny aktów regulujących materię współpracy publiczno-publicznej z wyjątkiem sklasyfikowanych jako poufne (art. 192 ust. 3 włoskiej ustawy o zamówieniach publicznych). Obowiązek ustawowy obejmuje również konieczność aktualizowania opublikowanych informacji. Rozpowszechnieniu ulegają zatem także akty modyfikujące sposób wykonania zadania publicznego.

Limitująco na możliwość udzielenia zamówienia in-house wpływa art. 192 ust. 2 omawianego aktu. Wskazany przepis wyraża obowiązek przeprowadzenia analizy ekonomicznej, porównującej koszt realizacji zamówienia wewnętrznego z kosztem powstałym w przypadku udzielenia zamówienia publicznego (test zasadności wysokości wynagrodzenia podmiotu wewnętrznego). Wskazany obowiązek ma sprzyjać efektywności wydatkowania środków publicznych i niedoprowadzeniu do sytuacji, w której wybrany sposób realizacji zadania będzie generował po stronie podmiotu wewnętrznego nieuzasadnione zyski. Analiza musi ponadto określić przyczyny odstąpienia od nabycia towarów lub usług w warunkach wolnorynkowych oraz wykazać korzyści wynikające z wyboru zinternalizowanej metody realizacji zadania publicznego w celu udowodnienia wyboru optymalnej metody zarządzania procesem nabywczym.

Pomimo że regulacje ustawowe nie formułują pierwszeństwa zamówień publicznych nad innymi formami realizacji zadań, w tym - jak podkreśla autorka zamówieniami wewnętrznymi czy partnerstwem publiczno-prywatnym, to jednak wprowadzając dodatkowe wymogi względem zamówień in-house, ograniczają zakres stosowania form alternatywnych.

Konrad Różowicz*

DOI: $10.14746 /$ spp.2020.1.29.12

* Konrad Różowicz, mgr, Uniwersytet im. Adama Mickiewicza w Poznaniu, e-mail: kr25863@amu.edu.pl, https://orcid.org/0000-0001-5885-4859. 